\title{
Cardiac disease in patients with mucopolysaccharidosis: presentation, diagnosis and management
}

\author{
Elizabeth A. Braunlin • Paul R. Harmatz • Maurizio Scarpa • Beatriz Furlanetto • \\ Christoph Kampmann • James P. Loehr • Katherine P. Ponder • William C. Roberts • \\ Howard M. Rosenfeld • Roberto Giugliani
}

Received: 18 April 2011 / Revised: 18 April 2011 / Accepted: 25 May 2011 / Published online: 9 July 2011

(C) The Author(s) 2011. This article is published with open access at Springerlink.com

\begin{abstract}
The mucopolysaccharidoses (MPSs) are inherited lysosomal storage disorders caused by the absence of functional enzymes that contribute to the degradation of glycosaminoglycans (GAGs). The progressive systemic deposition of GAGs results in multi-organ system dysfunction that varies with the particular GAG deposited and the specific enzyme mutation(s) present. Cardiac involvement has been reported in all MPS syndromes and is a common and early feature, particularly for those with MPS I, II, and VI. Cardiac valve thickening, dysfunction (more severe for left-sided than
\end{abstract}

Communicated by: Ed Wraith

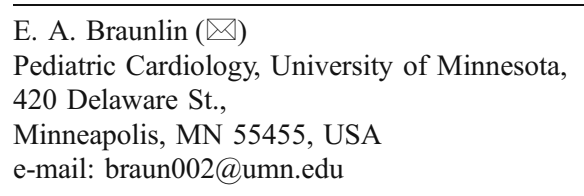

P. R. Harmatz

Children's Hospital \& Research Center Oakland,

Oakland, CA, USA

M. Scarpa

Department of Paediatrics, University of Padua,

Padua, Italy

B. Furlanetto

Pediatric Cardiac Surgery, Furlanetto Institute,

Hospital Beneficência Portuguesa,

São Paulo, Brazil

C. Kampmann

Department of Cardiology, University Children's Hospital,

Mainz, Germany

J. P. Loehr

Division of Pediatric Cardiology,

University of North Carolina at Chapel Hill,

Chapel Hill, NC, USA for right-sided valves), and hypertrophy are commonly present; conduction abnormalities, coronary artery and other vascular involvement may also occur. Cardiac disease emerges silently and contributes significantly to early mortality.

The clinical examination of individuals with MPS is often difficult due to physical and, sometimes, intellectual patient limitations. The absence of precordial murmurs does not exclude the presence of cardiac disease. Echocardiography and electrocardiography are key diagnostic techniques for evaluation of valves, ventricular dimensions and function,
W. C. Roberts

Baylor Heart and Vascular Institute, Baylor University Medical Center,

Dallas, TX, USA

H. M. Rosenfeld

Department of Cardiology,

Children's Hospital \& Research Center Oakland, Oakland, CA, USA

R. Giugliani

Department of Genetics, Federal University of Rio Grande do Sul, Medical Genetics Service, Hospital de Clínicas de Porto Alegre, and INAGEMP,

Porto Alegre, Brazil 
which are recommended on a regular basis. The optimal technique for evaluation of coronary artery involvement remains unsettled.

Standard medical and surgical techniques can be modified for MPS patients, and systemic therapies such as hematopoietic stem cell transplantation and enzyme replacement therapy (ERT) may alter overall disease progression with regression of ventricular hypertrophy and maintenance of ventricular function. Cardiac valve disease is usually unresponsive or, at best, stabilized, although ERT within the first few months of life may prevent valve involvement, a fact that emphasizes the importance of early diagnosis and treatment in MPS.

\section{Characteristics and implications of mucopolysaccharidosis}

The mucopolysaccharidoses (MPSs) are lysosomal storage disorders, characterized by the functional deficiency caused by genetic mutation of one of the particular lysosomal enzymes which act in the sequential catabolism of glycosaminoglycans (GAGs, formerly known as mucopolysaccharides) (Wraith 1995). Individuals with one of these rare metabolic disorders are affected by progressive accumulation of incompletely degraded GAGs within virtually all organ systems, although distribution varies depending on the specific disease (Wraith 1995). The characteristics of the currently recognized MPS disorders and their subtypes are summarized in Table 1.

Accumulation of partially-degraded GAGs progressively affects multiple organ systems and, possibly together with a cascade of secondary events, produces the classic phenotypes seen in these disorders. Typical manifestations include dwarfism (i.e. growth retardation), skeletal and joint deformities (e.g. dysostosis multiplex, including 'claw' hands), dysmorphic facial characteristics, central nervous system involvement (including mental retardation depending on type and severity, spinal cord compression and increased intracranial pressure), ocular (corneal clouding, retinal degeneration and blindness) and hearing impairment, respiratory difficulties, gastrointestinal pathology (e.g. hepatosplenomegaly, bowel dysfunction) and umbilical or inguinal hernias (Ferrari et al. 2011; Garcia et al. 2010; Lachman et al. 2010; Wraith 1995). The cardiovascular system is very commonly affected. While cardiac disease has been found in all of the MPS disorders, most studies indicate

Table 1 Characteristics of all known MPS types with respect to demographics, patients's specifics and genetic/biochemical profile (Compiled from (Neufeld and Muenzer 2001) and (Valayannopoulos et al. 2010))

\begin{tabular}{|c|c|c|c|c|c|}
\hline MPS type (eponym) & $\begin{array}{l}\text { Incidence per } \\
10^{5} \text { live births; } \\
\text { inheritance } \\
\text { pattern }\end{array}$ & $\begin{array}{l}\text { Typical age } \\
\text { at diagnosis }\end{array}$ & $\begin{array}{l}\text { Typical life expectancy } \\
\text { if untreated }\end{array}$ & Enzyme deficiency & GAG \\
\hline $\begin{array}{l}\text { MPS I Hurler (H) } \\
\text { MPS I Hurler- } \\
\text { Scheie (H-S) } \\
\text { MPS I Scheie (S) }\end{array}$ & $0.11-1.67 ; \mathrm{AR}$ & $\begin{array}{l}\mathrm{H}:<1 \text { year } \\
\text { H-S: 3-8 years S: } \\
\text { 10-20 years }\end{array}$ & $\begin{array}{l}\text { H: death in childhood } \\
\text { H-S: death in teens or early } \\
\text { adulthood S: normal to } \\
\text { slightly reduced lifespan }\end{array}$ & $\alpha$-L-iduronidase & DS, HS \\
\hline MPS II (Hunter) & $0.1-1.07 ; \mathrm{XR}$ & $\begin{array}{l}1-2 \text { years } \\
\text { when rapidly } \\
\text { progressing }\end{array}$ & $\begin{array}{l}\text { rapidly progressing: } \\
\text { death }<15 \text { years } \\
\text { slowly progressing: death in } \\
\text { adulthood }\end{array}$ & iduronate-2-sulfatase & DS, HS \\
\hline $\begin{array}{l}\text { MPS III } \\
\text { (Sanfilippo) } \\
\text { A-B-C-D }\end{array}$ & $0.39-1.89 ;$ AR & $4-6$ years & $\begin{array}{l}\text { death in puberty or early } \\
\text { adulthood }\end{array}$ & $\begin{array}{l}\text { heparan sulfamidase (A) } \\
\text { N-acetyl- } \alpha \text {-D-glucosaminidase (B) } \\
\text { acetyl-CoA- } \alpha \text {-glucosaminidase } \\
\text { N-acetyltransferase (C) } \\
\text { N-acetylglucosamine-6-sulfatase (D) }\end{array}$ & HS \\
\hline $\begin{array}{l}\text { MPS IV (Morquio) } \\
\text { A-B }\end{array}$ & $0.15-0.47 ;$ AR & $1-3$ years & $\begin{array}{l}\text { death in childhood- } \\
\text { middle age }\end{array}$ & $\begin{array}{l}\text { N-acetylgalactosamine-6-sulfatase (A) } \\
\beta \text {-galactosidase (B) }\end{array}$ & $\begin{array}{l}\text { CS, KS (A) } \\
\text { KS (B) }\end{array}$ \\
\hline $\begin{array}{l}\text { MPS VI } \\
\text { (Maroteaux- } \\
\text { Lamy) }\end{array}$ & $0-0.38 ; \mathrm{AR}$ & $\begin{array}{l}\text { rapidly progressing: } \\
1-9 \text { years } \\
\text { slowly progressing: } \\
>5 \text { years }\end{array}$ & $\begin{array}{l}\text { rapidly progressing: death } \\
\text { in } 2 \text { nd-3rd decade } \\
\text { slowly progressing: death in } \\
4-5^{\text {th }} \text { decade }\end{array}$ & $\mathrm{N}$-acetylgalactosamine-4-sulfatase & DS \\
\hline MPS VII (Sly) & $0-0.29 ; \mathrm{AR}$ & $\begin{array}{l}\text { neonatal to } \\
\text { adulthood }\end{array}$ & $\begin{array}{l}\text { death in infancy- } \\
\text { 4th decade** }\end{array}$ & $\beta$-D-glucuronidase & CS, DS, HS \\
\hline $\begin{array}{l}\text { MPS IX } \\
\text { (Natowicz)* }^{*}\end{array}$ & unknown & adolescence & unknown & hyaluronidase & $\mathrm{CS}$ \\
\hline
\end{tabular}

AR: autosomal recessive; CS: chondroitin sulfate; DS: dermatan sulfate; GAG: glycosaminoglycan; H: Hurler syndrome; HS: heparan sulfate; H-S: Hurler-Scheie syndrome; KS: keratan sulfate; S: Scheie syndrome; XR: X-linked recessive

*only 1 patient reported in literature (Natowicz et al. 1996); **death can occur in utero with hydrops fetalis 
that it occurs earlier and more frequently in MPS I, II, and VI (Chen et al. 2005; Dangel 1998; Fesslová et al. 2009; Gross et al. 1988; Leal et al. 2010; Mohan et al. 2002; Wippermann et al. 1995) than in MPS III or IV, while the frequency in MPS VII is difficult to judge due to the small number of patients.

Clinical findings and severity depend on the particular MPS syndrome, the specific genetic mutations involved (Karageorgos et al. 2007; Matte et al. 2003; Yogalingam et al. 2004) and, to some extent, on the individual patient's biology with other, still undefined factors that lead to variability in phenotype within MPS syndromes. Based on severity and age at onset, some of the MPS syndromes have been categorized into slowly- and rapidly-progressing phenotypic subtypes (Jones et al. 2009; Muenzer et al. 2009b; Neufeld and Muenzer 2001; Schwartz et al. 2007; Swiedler et al. 2005; Thomas et al. 2010). Phenotypic heterogeneity is seen in all types of MPS (Martins et al. 2009; Muenzer et al. 2009b; Neufeld and Muenzer 2001). The rapidly progressing form of MPS I (i.e. Hurler syndrome) is associated with central nervous system involvement and early-onset cardiac disease (Brosius and Roberts 1981; Neufeld and Muenzer 2001). Phenotypic severity, including mortality, in MPS II has been based, thus far, on the degree of developmental delay and GAG excretion (Jones et al. 2009; Schwartz et al. 2007). While central nervous system involvement does not play a role in MPS VI, phenotypic severity in somatic growth and pulmonary function has been correlated with urinary GAG excretion (Swiedler et al. 2005).

Regardless of phenotype, all forms of MPS are associated with morbidity and early mortality (Table 1) (Brosius and Roberts 1981; Giugliani et al. 2007; Jones et al. 2009; Martins et al. 2009). Premature death in untreated MPS syndromes is most commonly a result of respiratory compromise and cardiac disease (Chen et al. 2005; Gross et al. 1988; Jones et al. 2009; Krovetz et al. 1965). Reported cardiac causes of death include heart failure, sudden death from arrhythmias (including complete atrioventricular block) (Hishitani et al. 2000; Martins et al. 2009) and coronary occlusion (Lin et al. 2005).

\section{Cardiac disease associated with MPS}

\section{Early reports}

Cardiac findings were not prominent in the earliest reports of Hurler syndrome (Hurler 1919) and Hunter syndrome (Hunter 1917). Beginning in the 1940-50s, detailed postmortem cardiac studies on individuals clinically diagnosed with MPS (previously referred to as "gargoylism") were reported by several investigators (Emanuel 1954; Lindsay 1950; Strauss 1948). These early morphologic studies occurred well before the biochemical basis of MPS disorders was established. It was only in 1965 that Victor McKusick, trained as a cardiologist and the father of modern medical genetics, established the classification of the MPS disorders based upon patterns of mucopolysacchariduria, a system that continues, with few changes, to be in use today (Kaplan 1969; McKusick et al. 1965; McKusick 1969). The first MPS cardiac studies to include supporting biochemical data are those of Krovetz et al. (Krovetz et al. 1965), Renteria et al. (Renteria et al. 1976) and Brosius and Roberts (Brosius and Roberts 1981).

Prevalence, severity and time of onset

Because of the rarity of the disorders (Table 1), cardiac studies involving large numbers of individuals with a particular MPS are uncommon. Nevertheless, the prevalence and severity of cardiovascular disease in individuals with MPS (especially MPS I, II and VI) is strikingly high, occurring in $60-100 \%$ of those studied (Chen et al. 2005; Dangel 1998; Fesslová et al. 2009; Leal et al. 2010; Martins et al. 2009; Pastores et al. 2007; Wippermann et al. 1995). Cardiac valve involvement appears more common in those syndromes in which dermatan sulfate catabolism is deranged (MPS I, II and VI but not MPS III and IV) (Chen et al. 2005; Dangel 1998; Fesslová et al. 2009; Leal et al. 2010).

Within a particular type of MPS, cardiac pathology generally develops earlier in life for individuals with more rapidly progressing types of MPS (e.g. Hurler syndrome) (Brosius and Roberts 1981; Hirth et al. 2007) and may be delayed in slowly progressing forms (e.g. Hurler-Scheie and Scheie syndromes) (Soliman et al. 2007). Nonetheless, cardiac disease is a uniformly progressive process (Chen et al. 2005; Dangel 1998; Fesslová et al. 2009; Giugliani et al. 2007; Krovetz et al. 1965; Leal et al. 2010; Mohan et al. 2002; Muenzer et al. 2009b) with both incidence and severity increasing over time (Fesslová et al. 2009). Despite this, clinical signs and symptoms of cardiac involvement are uncommon leading to an underestimate of the true prevalence of cardiac disease. For example, only six of 26 patients with documented echocardiographic disease presented with cardiovascular signs or symptoms (Dangel 1998; Gross et al. 1988; Leal et al. 2010), a finding which underscores the importance of a complete cardiac evaluation after establishing a diagnosis of MPS.

Valvular disease

Progressive cardiac valve pathology is the most prominent and uniform cardiac manifestation (60-90\%) of patients with MPS (Fesslová et al. 2009; Wippermann et al. 1995). Cardiac valve thickening with associated dysfunction has been reported in more than $80 \%$ of patients with MPS I 
(including slowly progressing phenotypes) (Pastores et al. 2007; Thomas et al. 2010), 57\% of patients with MPS II (Wraith et al. 2008) and in all individuals with MPS VI except for the most slowly progressing ones (Azevedo et al. 2004; Brooks et al. 2005; Scarpa et al. 2009).

Most studies have reported that valvular regurgitation, rather than stenosis, is more common and that the mitral valve, rather than the aortic, is most commonly affected. In general, left-sided valves (mitral \& aortic) are more severely affected than those on the right side of the heart (tricuspid \& pulmonary) (Dangel 1998; Fesslová et al. 2009; Krovetz et al. 1965; Rigante and Segni 2002; Thomas et al. 2010). The mitral valve leaflets are markedly thickened and cartilage-like, with particularly thickened edges (Fig. 1). The subvalvular apparatus of the mitral valve develops shortened chordae tendineae and thick papillary muscles resulting in dysmorphic and poorly
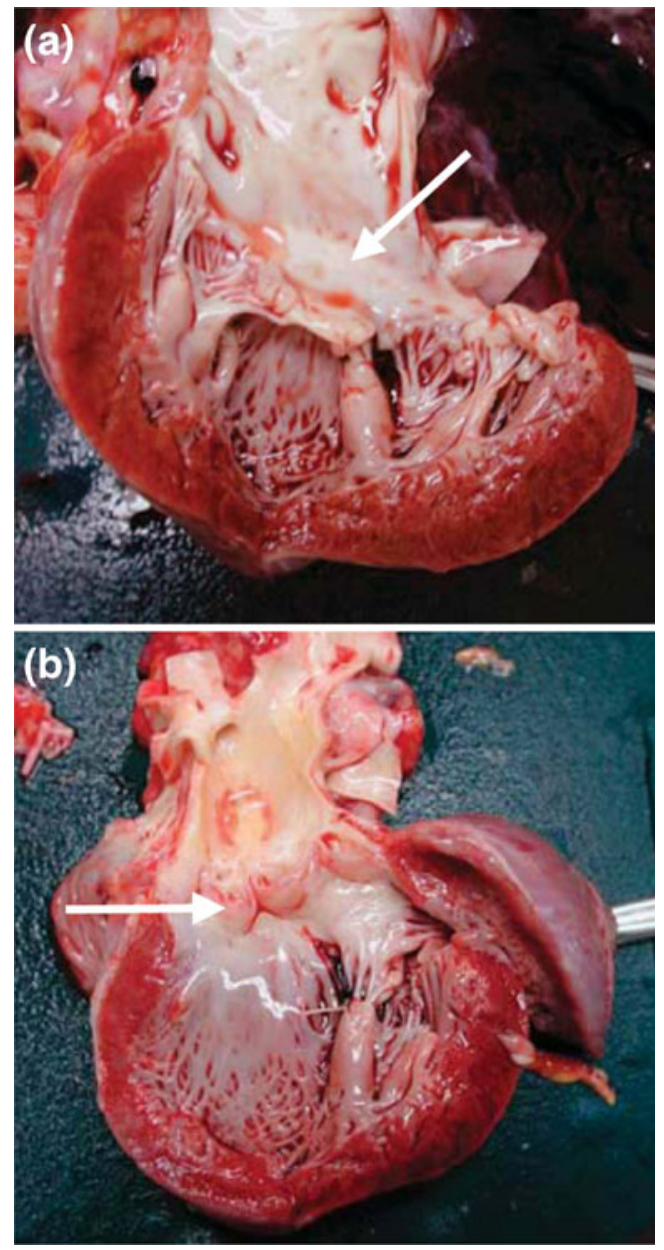

Fig. 1 (a) Autopsy specimen from a female patient with Hurler syndrome at the age of 2.8 years showing (a) a dysplastic and thickened mitral valve (arrow) with a thickened subvalvular apparatus and parietal left ventricular hypertrophy and (b) a dysplastic aortic valve (arrow) (Fesslová et al. 2009) (copyright Fesslová et al. Cardiol Young 2009) mobile leaflets (Fig. 1) (Tan et al. 1992; Yano et al. 2009). Calcific deposits commonly occur in the mitral annular region (Johnson et al. 1981; Renteria et al. 1976). The aortic valve presents a similar picture of progressive valve thickening and dysfunction (Fig. 1).

These pathologic alterations result in regurgitation (insufficiency) and/or stenosis, both of which are easily identified by two-dimensional echocardiography and Doppler examination (Johnson et al. 1981; Maganti et al. 2010) (Fig. 2). Valvular stenosis or regurgitation may lead to left atrial and/or left ventricular volume overload, left ventricular dilatation, left ventricular hypertrophy (LVH), and ultimately to systolic and diastolic dysfunction. In a retrospective case series of children with various forms of MPS, LVH and diastolic dysfunction emerged at an early stage, whereas left ventricular dilation and systolic dysfunction occurred at older ages and later disease stage (Leal et al. 2010) (Fig. 3).

\section{Coronary artery disease}

Coronary artery narrowing and/or occlusion has been described in individuals with all types of MPS (Braunlin et al. 1992; Brosius and Roberts 1981; Danks et al. 1972; Factor et al. 1978; Kettles et al. 2002; Kurihara et al. 1996; Renteria et al. 1976; Shimamura et al. 1976; Tan et al. 1992), but is most common in MPS I and MPS II. Diffuse intimal proliferation from GAG deposition within large epicardial coronary arteries can occur early, especially in rapidly progressing MPS I (Brosius and Roberts 1981), causing high-grade narrowing (Fig. 4). The lumens are nearly always central in location. Occlusion within coronary arterioles (rather than in the large epicardial coronary arteries) and a large left ventricular apical aneurysm have been described in an individual with MPS VI suggesting that different types of coronary involvement may occur in the various MPS syndromes (Oudit et al. 2007). A similar apical aneurysm has been reported in MPS II (Kettles et al. 2002), although a description of the coronary arterioles was not provided.

\section{Other vascular changes}

The great vessels in individuals with MPS may have increased wall thickness and may either be narrowed (Taylor et al. 1991; Wraith et al. 2008) or dilated (Hinek and Wilson 2000). Diffuse narrowing of the thoracic and abdominal aorta (Taylor et al. 1991) has been reported to occur in $30 \%$ of a small series of individuals with MPS I and II. Narrowing may occur at the aortic isthmus, a location typical for coarctation (Braunlin et al. 2000), and may require surgical intervention for relief of significant obstruction. Although systemic hypertension due to arterial narrowing is common among individuals with MPS I and II (Taylor et al. 1991; Wraith et al. 2008), it has been less 
Fig. 2 Echocardiography and Doppler interrogation of mitral (a) and aortic (b) valve in a 50-year-old male with MPS VI (a) Short-axis view of thickened mitral valve (arrow) in diastole (left). Colour Doppler demonstration of mitral regurgitation (right). (b) Shortaxis view demonstrating thickened trileaflet aortic valve (arrow) in systole (left). Colour Doppler demonstrating turbulent systolic flow of aortic valve stenosis (right)

\section{(a)}


(b)
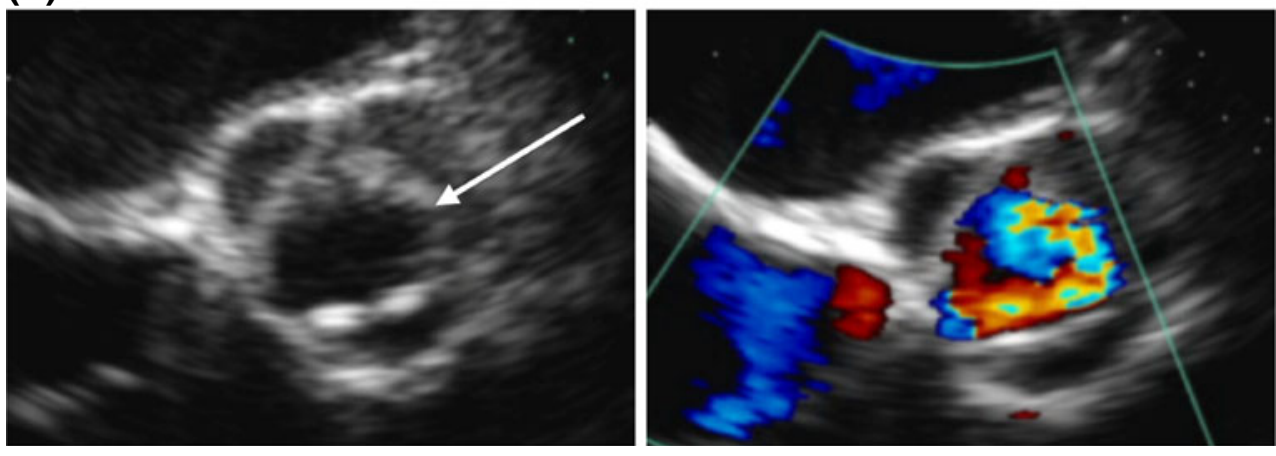

frequently noted in other types of MPS (including MPS VI) (Giugliani et al. 2007).

Dilation of the ascending aorta and markedly reduced aortic elasticity has been reported in MPS I (Nemes et al. 2008). This could be attributed to the downstream effects of GAGs on the assembly of tropo-elastin, resulting in elastin that is both decreased in content and abnormal in structure

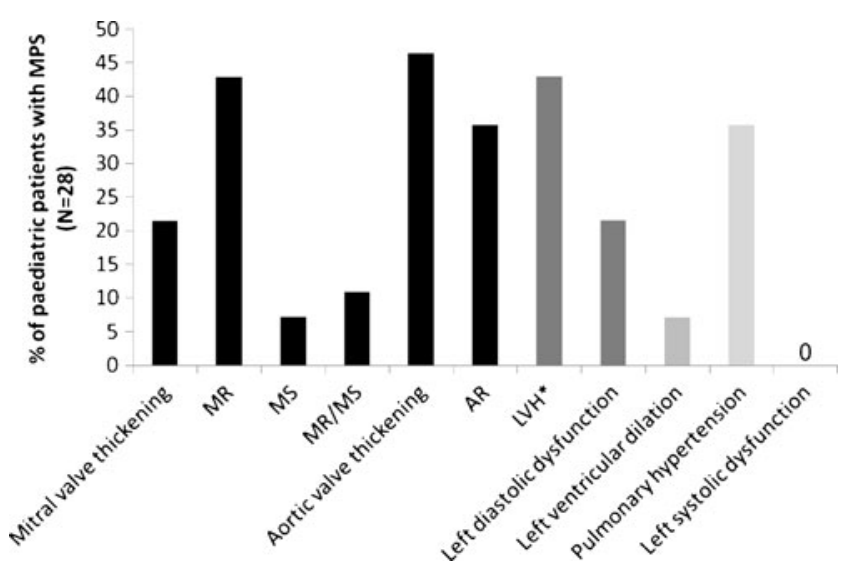

Fig. 3 Echocardiographic evaluations in patients with MPS (214 years old, mean age 9 years; MPS I-II-III-IV-VI-VII) indicate that left valve lesions, left ventricular hypertrophy (LVH) and pulmonary hypertension are the most common cardiac findings (Leal et al. 2010). AR: aortic regurgitation; MR: mitral regurgitation; MS: mitral stenosis; MR/MS: both lesions; ${ }^{*} \mathrm{LVH}$ : septal and posterior wall hypertrophy of left ventricle
(Hinek and Wilson 2000). Studies in MPS I and MPS VII animals have revealed that aortic dilation is likely due to degradation of elastin by matrix metalloproteinase-12 and/or cathepsin S (Ma et al. 2008; Metcalf et al. 2010). Aortic root replacement has not been reported for MPS patients to date.

\section{Conduction abnormalities}

Conduction abnormalities and sinus tachycardia have been reported in $44 \%$ of the patients with MPS VI and in $7 \%$ of a subset of the Hunter Outcome Survey of MPS II patients, respectively (Azevedo et al. 2004; Wraith et al. 2008). Several case reports have documented the development of



Fig. 4 Epicardial right coronary artery from untreated 1-year-old male with rapidly progressing MPS I. Note diffuse myointimal proliferation (arrow). (Alcian blue stain) 
complete atrioventricular block (MPS II, III and VI) with subsequent need for cardiac pacing and sudden death (Dilber et al. 2002; Hishitani et al. 2000; Misumi et al. 2010). Fibrosis of the conduction system with GAG infiltration was seen in one individual with MPS VI who died suddenly (Keller et al. 1987).

\section{Underlying cardiac pathology}

Although the pathobiology of MPS is incompletely understood, it is generally assumed that the influence of progressive GAG infiltration and its downstream effects are responsible for anatomical and functional alterations of the valves, coronary arteries, great vessels, conduction system and myocardium (Hinek and Wilson 2000; Martins et al. 2009).

Cardiac histopathology and electron microscopy are most complete in MPS I. These characteristically show increased GAG content as well as infiltration of 'clear' cells and granular cells within cardiac valves (leaflets, annuli and chordae tendineae), endocardium, myocardial walls, coronary arteries, aorta (Renteria et al. 1976) and the conduction system (Hishitani et al. 2000). Examination of heart tissue by light microscopy shows the morphological consequences of GAG storage, i.e. vacuolated cells with enlarged cytoplasm (Fig. 5).

\section{Role of GAGs in pathogenesis}

The heparan-, dermatan-, chondroitin- and keratan-sulfated GAGs are normal components of cardiac valves and the great vessels (Grande-Allen et al. 2003; Gupta et al. 2009; Latif et al. 2005). Recent studies have implicated alterations in proteoglycan (GAG) metabolism in pathological processes such as myxomatous mitral valves (Grande-Allen et al. 2003; Rabkin et al. 2001), aortic aneurysm (Theocharis et al. 2003),

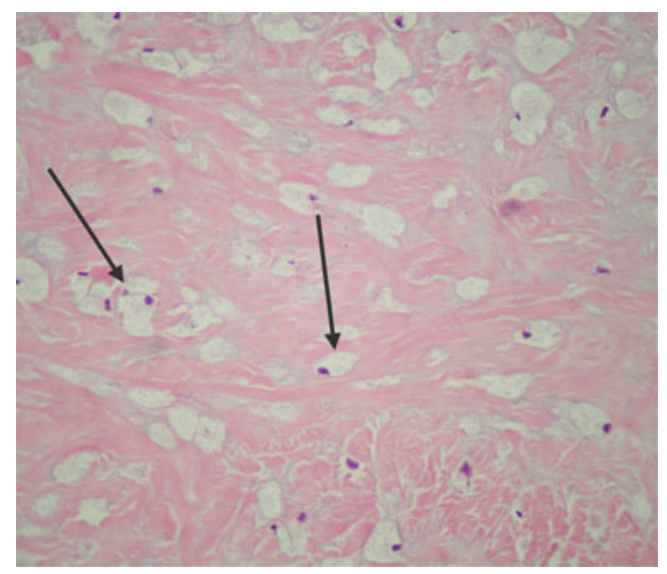

Fig. 5 Light microscopy of the mitral valve of a girl with MPS VI at 14 years of age, demonstrating enlarged and foamy appearing fibroblasts (arrows) (hematoxylin and eosin staining, magnification x 20) and atherosclerotic vasculature (Nakashima et al. 2008). Dermatan-sulfated GAGs are a prominent component of normal cardiac valve tissue (Latif et al. 2005) so it is not surprising to find a strong association between MPS I, II and VI (that result in the accumulation of dermatan-sulfated GAGs) and cardiac valve disease (Dangel 1998; Leal et al. 2010). Additionally, deep within the cardiac valves of all MPS syndromes, lie GAG-laden cells that have variously been called 'clear' cells, 'Gargoyle' cells or 'Hurler' cells. Recently, these cells have been identified in MPS I as being activated valvular interstitial cells engaged in attempted, but ineffective, valve repair (Braunlin et al. 2010). The mechanisms by which the accumulated heparan-sulfated proteoglycans and attendant vascular interstitial cells affect the vasculature of the great vessels and coronary arteries in MPS I, II, and III (the heparan-sulfate accumulating MPS disorders) remains unknown. One hypothesis for the role of GAGs in cardiac disease could be that GAGs induce inflammation by activating the Toll-like receptor 4 pathway, leading to upregulation of degradative proteases (Simonaro 2010).

\section{Diagnosis and regular monitoring of cardiac disease in MPS}

Physical examination

The physical examination not only of young children, but also of adults with MPS is challenging due to both physical and, sometimes, intellectual patient limitations. A complete examination includes right upper as well as lower extremity blood pressures (to exclude aortic obstruction), pulse rate, palpation of pulses in all extremities, as well as careful auscultation of the heart and lungs. Other aspects of a complete cardiac examination, evaluating jugular venous distention or hepatosplenomegaly, may be unrewarding due to shortened necks and the presence of GAG-laden and enlarged visceral organs. Dysostosis multiplex and joint stiffening may complicate blood pressure measurements. Auscultation is often suboptimal due to pronounced upper airway noises. While the cardiac sounds are generally easily heard, the absence of cardiac murmurs does not exclude the presence of significant cardiac disease. Mild to moderate degrees of valvular stenosis and/or regurgitation can be present without significant murmurs.

Non-invasive techniques

Because of its versatility, ease of performance and costeffectiveness, transthoracic two-dimensional echocardiography is the primary imaging modality used to evaluate cardiac anatomy and function in patients with MPS (Aguilar et al. 2008). Echocardiography provides reliable measurements of 
ventricular chamber dimensions (both systolic and diastolic) and left ventricular posterior and septal wall thicknesses, which can be normalized for body surface area. Accurate measures of ventricular function (shortening fraction \& ejection fraction) can be determined. Doppler interrogation of cardiac valves allows accurate grading of valve stenosis and regurgitation as well as estimation of cardiac output and right ventricular/pulmonary artery pressures (Aguilar et al. 2008). Despite its benefits, echocardiography provides only limited information in the assessment of coronary artery anatomy and pathology. Transthoracic echocardiography can usually be performed without sedation if the child is allowed to remain in his parent's arms or if he can be distracted by videos or toys. In some instances, however, transthoracic echocardiography may be suboptimal due to limited tolerance for examination, abnormal cardiac position, scoliosis, or hyper-aerated lung fields. Transesophageal echocardiography is not routinely employed in those with MPS as it requires monitored sedation or general anaesthesia, which may be poorly tolerated because of the airway complications that are not infrequent in this patient population.

Magnetic resonance imaging (MRI) and computed tomography (CT) are advanced techniques not routinely used for cardiac evaluation in children. Although MRI is a reliable tomographic technique for assessing cardiac anatomy and function (with quantification of volumetrics and regurgitation), its application is limited by heart rate constraints, slow acquisition times, and the need for sedation, and may be contraindicated in individuals with implanted devices (Aguilar et al. 2008). Cardiac CT angiography, advantageous with respect to acquisition speed and resolution, is limited by relatively large radiation exposure and suboptimal assessment of valve morphology and hemodynamics (Aguilar et al. 2008).

Evaluation for the presence of coronary arteriopathy in the MPS disorders is problematic because the diffuse nature of coronary involvement differs substantially from typical atherosclerotic coronary disease. While the latter is believed to be reliably excluded by a normal CT angiogram (Taylor et al. 2010), this may not be true in MPS coronary disease. Coronary angiography may be therefore indicated in those suspected of having coronary artery pathology (Winchester et al. 2010), but may miss significant disease due to the diffuse nature of the process in MPS (Braunlin et al. 1992). Intravascular ultrasound has successfully identified significant coronary artery narrowing in adults with Fabry's disease (Kovarnik et al. 2008), but has not been reported in the MPS disorders and remains primarily a research tool. The value of non-invasive dobutamine or adenosine stress testing combined with echocardiography or MRI imaging is currently under study in individuals with MPS.

Standard 12-lead electrocardiography (ECG) is the second most important technique used to evaluate the hearts of individuals with MPS. Assessment of heart rate and rhythm as well the determination of conduction times (PR interval, QRS duration, corrected QT interval) are all important clues to the health of the underlying conduction system. In instances where symptoms suggestive of either conduction block or arrhythmia are present, more prolonged monitoring (Holter or event monitor) is required for identifying arrhythmias and heart rate variability. Although rarely detected on routine ECG, one should pay attention for signs of ischemia in this patient population.

\section{Recommendations}

Individuals with MPS should undergo physical examination, echocardiography and 12-lead ECG at the time of diagnosis, followed by regular monitoring (every 1 to 2 years for MPS I and VI, or 1 to 3 years for MPS II) thereafter in order to provide appropriate diagnosis and management (Giugliani et al. 2007; Muenzer et al. 2009a, b). Additional cardiac evaluations should be considered before major operative interventions. Complete evaluation includes right arm and leg blood pressure measurements, careful auscultation, performance of a full transthoracic two-dimensional and Doppler echocardiogram, 12-lead ECG, and Holter monitoring as indicated (Giugliani et al. 2007; Muenzer et al. 2009a, b). Performance and interpretation of echocardiography should be standardized (in terms of equipment and settings) and provided by individuals familiar with expected pathological findings in patients with MPS (Fig. 6).

\section{Management of cardiac disease in MPS}

Current patient management is dependent upon the type of MPS present and may include standard pharmacological and surgical care, enzyme replacement therapy (ERT) or hematopoietic stem cell transplantation (HSCT). While standard medical care has focused on medications for heart failure and cardiac surgery (Valayannopoulos et al. 2010), systemic therapies aim to restore functional enzyme and slow, or possibly reverse, disease progression. Systemic therapies have been shown to lengthen life (HSCT) and to improve clinical status (HSCT and ERT), particularly when performed early in life (Martins et al. 2009; Muenzer et al. 2009a; Prasad and Kurtzberg 2010b; Valayannopoulos et al. 2010).

Pharmacological and surgical approaches

In the adult population, standard pharmacological and surgical management has been driven by cardiac pathophysiology regardless of MPS type. One longitudinal cohort study reported $33 \%$ of 48 patients with MPS received standard drug therapy for hemodynamic complications caused by valvular 
Fig. 6 Recommended diagnostic techniques and assessments to evaluate cardiac anatomy and function in patients with MPS at initial diagnosis and at regular intervals thereafter (every 1 to 2 years for MPS I and VI, or 1 to 3 years for MPS II) 2D: 2-dimensional; ECG: electrocardiography; ECHO: echocardiography



lesions or heart failure (Fesslová et al. 2009). In the pediatric population, due to the absence of large-scale, long-term pharmacological studies, clear recommendations regarding pharmacologic management have not been defined (O'Connor et al. 2010). Afterload reduction with angiotensin-converting enzyme inhibitors or angiotensin II receptor blockers has been reported as useful in small series of non-MPS children with aortic or mitral regurgitation, hypertension or heart failure (O'Connor et al. 2010). Although these drugs are frequently used, formal recommendations have yet to be made regarding their use in children, either with or without MPS (O'Connor et al. 2010).

Progressive deposition of GAGs within the cardiac valves can lead to regurgitation or stenosis severe enough to require surgical intervention. Cardiac valve surgery is among the procedures frequently performed in patients with MPS (Arn et al. 2009). Successful valve repair or replacement has been reported in individuals with all types of MPS (Table 2). Mitral valve replacement was performed in MPS I (Kitabayashi et al. 2007; Kraiem et al. 2001), MPS II (Antoniou et al. 2009) and MPS VI (Marwick et al 1992); a 6-year-old with MPS III (Muenzer et al. 1993) has undergone mitral valvuloplasty. Successful aortic valve replacement has been reported in adults with slowly progressing MPS I (Masuda et al. 1993), MPS IV (Barry et al. 2006; Nicolini et al. 2008; Pagel and Almassi 2009) and MPS VI (Wilson et al. 1980). Due to pathological abnormalities in the native pulmonary root, the Ross procedure, where the aortic valve is replaced by the patient's own pulmonary valve, is contraindicated in individuals with MPS (Barry et al. 2006). Combined aortic and mitral valve replacement was successfully performed in adults (Butman et al. 1989; Fischer et al. 1999; Minakata et al. 1998) and in teens as young as 12 years of age (Goksel et al. 2009) with MPS I and in adults with MPS II (Joly et al.
2004) and MPS VI (Hachida et al. 1996; Tan et al. 1992). Fesslová et al. have reported favorable mitral and aortic valve replacement in three patients with Scheie syndrome and one with slowly progressing Hunter syndrome ranging in age from 13-53 years (Fesslová et al. 2009). Other successful cardiac procedures include coronary artery bypass surgery in a 56-year-old male with slowly progressing MPS I (Minakata et al. 1998), closure of an outlet type of ventricular septal defect in a child with MPS III (Kourouklis et al. 2007), and repair of 'coarctation' of the aorta after HSCT in a 3-year-old boy with rapidly progressing MPS I (Braunlin et al. 2000).

While the long-term outcome is generally favorable (Hachida et al. 1996; Marwick et al. 1992; Tan et al. 1992; Wilson et al. 1980), candidacy for surgical intervention must be based on general health status and potential risks posed by intubation and post-operative care. Craniofacial abnormalities, excessive oral pharyngeal and upper airway tissue, a short stiff neck, and unstable atlantoaxial joint (with risk of spinal cord injury) (Giugliani et al. 2007) may combine to complicate intubation and airway management in select patients (Walker et al. 1994). Intubation with use of fiber-optic bronchoscope and expertise in dealing with uncommon airway issues in this patient population is often necessary. Endocarditis prophylaxis is currently recommended only in patients with a history of endocarditis, certain residual postoperative lesions, or a prosthetic valve (Maganti et al. 2010; Wilson et al. 2007).

Systemic therapies

HSCT has been successfully employed for metabolic correction of MPS disorders for the past 30 years (Hobbs et al. 1981; Krivit et al. 1984). While this therapeutic approach has, in the rapidly progressing form of MPS I, 
Table 2 Successful cardiac operative procedures in MPS disorders

\begin{tabular}{|c|c|c|}
\hline $\begin{array}{l}\text { Operative procedure } \\
\text { performed }\end{array}$ & $\begin{array}{l}\text { Type MPS (patient age } \\
\text { in years/gender) }\end{array}$ & References \\
\hline \multirow[t]{4}{*}{ Mitral valve replacement } & $\mathrm{I}-\mathrm{S}(41 \mathrm{~F})$ & (Kitabayashi et al. 2007) \\
\hline & $\mathrm{I}-\mathrm{H}(16 \mathrm{~F})$ & (Kraiem et al. 2001) \\
\hline & II $(33 \mathrm{M})$ & (Antoniou et al. 2009) \\
\hline & VI $(25 \mathrm{~F})$ & (Marwick et al. 1992) \\
\hline Mitral valvuloplasty & III (6 F) & (Muenzer et al. 1993) \\
\hline \multirow[t]{3}{*}{ Aortic valve replacement } & $\mathrm{I}-\mathrm{S}(62 \mathrm{M})$ & (Masuda et al. 1993) \\
\hline & IV (31 F; $41 \mathrm{M})$ & $\begin{array}{l}\text { (Nicolini et al. 2008; Pagel and } \\
\text { Almassi 2009) }\end{array}$ \\
\hline & VI $(43 \mathrm{M})$ & (Wilson et al. 1980) \\
\hline Ross procedure* & IV (32 F) & (Barry et al. 2006) \\
\hline \multirow{4}{*}{$\begin{array}{l}\text { Aortic and mitral valve } \\
\text { replacement }\end{array}$} & $\mathrm{I}(12 \mathrm{M})$ & (Goksel et al. 2009) \\
\hline & I-S (23-35 M; $42 \mathrm{~F} ; 52 \mathrm{M})$ & $\begin{array}{l}\text { (Butman et al. 1989; Fischer et al. 1999; } \\
\text { Minakata et al. 1998) }\end{array}$ \\
\hline & II $(18 \mathrm{M})$ & (Joly et al. 2004) \\
\hline & VI (21 F, 30 M, 34 F; 41 M) & (Hachida et al. 1996; Tan et al. 1992) \\
\hline Coronary artery bypass & $\mathrm{I}-\mathrm{S}(56 \mathrm{M})$ & (Minakata et al. 1998) \\
\hline $\begin{array}{l}\text { Ventricular septal defect } \\
\text { closure }\end{array}$ & III (15 M) & (Kourouklis et al. 2007) \\
\hline Coarctectomy & $\mathrm{I}-\mathrm{H}(3 \mathrm{M})$ & (Braunlin et al. 2000) \\
\hline
\end{tabular}

F: female; I-H: Hurler syndrome; I-S: Scheie syndrome; M: male

*aortic valve replacement by autologous pulmonary valve graft
MPS II (Muenzer et al. 2006) and galsulfase for MPS VI (Harmatz et al. 2004; Harmatz et al. 2005). Cross-correction with ERT is achieved in many organs and tissues, reflected by lower urinary GAG levels and symptomatic improvement. While galsulfase infusion has been shown to produce improvement in endurance (walk and stair climb test, sustained up to 5 years), pulmonary function, joint pain and stiffness, and growth and organomegaly (Harmatz et al. 2004; Harmatz et al. 2005; Harmatz et al. 2006; Harmatz et al. 2008), the outcome of ERT is less favorable for poorly vascularised or "privileged" sites (central nervous system, cornea, articular cartilage, and cardiac valves).

The effect of ERT alone on cardiac structure and function in patients with MPS is documented in only a few studies (Braunlin et al. 2006; Fesslová et al. 2009; Okuyama et al. 2010; Scarpa et al. 2009; Wraith et al. 2007). As with HSCT, long-term ERT preserves, and may even improve (Hirth et al. 2007), systolic ventricular function and results in resolution of ventricular hypertrophy in adults and children with MPS I and II (Braunlin et al. 2006; Okuyama et al. 2010; Wraith et al. 2007). However, ERT does not appear to prevent progression of left-sided cardiac valve thickening and dysfunction (stenosis, regurgitation) in MPS I, II and VI. Stabilization of valvular disease in select patients over a limited study period has been observed (Braunlin et al. 2006; Fesslová et al. 2009; Okuyama et al. 2010; Scarpa et al. 2009). ERT has been used as an adjunct in MPS I to lower the GAG burden prior to HSCT (Tolar and Orchard 2008) and, recently, galsulfase has been found 
to normalize mild elevations in GAG levels found in a single fully-engrafted patient with MPS VI 20 years after successful HSCT (Whitley and Utz 2010). Whether these protocols will have beneficial cardiac effects remains unstudied.

In contrast to the young age at which most individuals with MPS undergo HSCT, ERT is usually begun in the older child (often after 5 years of age) with established cardiac valvular disease. It is possible that earlier use of ERT may prevent or ameliorate cardiac valve thickening and dysfunction in MPS as has been shown by two recent sibling studies (Gabrielli et al. 2010; McGill et al. 2010) (Table 3). Each older sibling with either MPS I or MPS VI shared the same enzyme mutation as his younger sibling and differed only in the age at diagnosis. The older sibling in each instance, starting with ERT at 4 or 5 years of age, retained the classic phenotypical appearance of MPS as well as thickening, regurgitation or dysplasia of the mitral valve (Table 3). By contrast, each younger sibling, treated with ERT from 8 weeks and 5 months of age and onwards, respectively, appeared phenotypically normal and had virtually no cardiac pathology by echocardiography either before, or after, ERT (Table 3). These data underscore the importance of newborn or early screening for MPS as there appears to be a window in early infancy when ERT may prevent many of the end-organ manifestations of MPS.

\section{Future perspectives}

A major step forward in the diagnosis and care of patients with MPS would be the development, implementation, and roll-out of a multi-tier screening procedure in newborns. This screening will identify pre-symptomatic newborns, allowing for early treatment and prevention or limitation of morbidity (Marsden and Levy 2010). Continued efforts are being made to develop easy, reliable and specific blood and urinary tests for MPS detection based on enzyme activity, enzyme levels or GAG levels. After validation, it would be ideal if the existing newborn screening programme will be expanded to include MPS in addition to other lysosomal storage disorders.

Additionally, improvements in the choice of donor cells for HSCT may improve long-term results and result in lower procedure-induced mortality. In as much as cartilage and heart valves are both of mesenchymal origin, use of mesenchymal cells in conjunction with, or after, HSCT may provide potential to correct tissues currently unresponsive to either HSCT or cord blood transplantation alone (Boelens 2006). A small number of patients with rapidly progressing MPS I have received mesenchymal cells in addition to HSCT (Koç et al. 2002), but results were inconclusive and further research was recommended.

Finally, results with genetically modified viral vectors have shown prevention of cardiac valve pathology in dogs with MPS I or VII (Ponder et al. 2002; Sleeper et al. 2004; Traas et al. 2007), in mice with MPS I that have very high serum enzyme after neonatal injection of a retroviral vector (Liu et al. 2005), and in a mouse that received HSCT-directed gene therapy (Jordan et al. 2005). The use of gene therapy, including autologous cells treated with viral vectors and then auto-transfused, remains untested in humans with MPS.

\section{Concluding remarks}

Progress in our understanding of MPS has increased significantly since Hunter and Hurler first reported their findings. Early case reports were methodically compiled and systematized by Victor McKusick into the classification scheme that has served us now for nearly 50 years
Table 3 Impact of early initiation of enzyme replacement therapy (ERT) on the course of MPS according to openlabel, case-control studies in sibling (sib) pairs

\begin{tabular}{|c|c|c|c|}
\hline \multirow[t]{2}{*}{ Study details } & \multirow[t]{2}{*}{ Sibling (gender) } & \multicolumn{2}{|c|}{ Echocardiographic abnormalities } \\
\hline & & At start of ERT (age) & Post-ERT (age) \\
\hline \multirow{2}{*}{$\begin{array}{l}\text { MPS I Hurler-Scheie (Gabrielli } \\
\text { et al. 2010) } 5 \text { years ERT at } \\
100 \mathrm{U} / \mathrm{kg} \text { body weight weekly }\end{array}$} & Sib 1 (male) & None (5 months) & $\begin{array}{l}\text { None (5 years } \\
\text { and } 5 \text { months) }\end{array}$ \\
\hline & Sib 2 (female) & $\begin{array}{l}\text { Moderate MR with } \\
\text { thickened valve } \\
\text { leaflets and anterior } \\
\text { edge prolapsed; mild } \\
\text { LA thickening ( } 5 \text { years) }\end{array}$ & $\begin{array}{l}\text { Stabilized cardiac } \\
\text { function without } \\
\text { improvement } \\
\text { (10 years) }\end{array}$ \\
\hline \multirow{2}{*}{$\begin{array}{l}\text { MPS VI (McGill et al. 2010) } \\
3.5 \text { years ERT at } 1 \mathrm{mg} / \mathrm{kg} \\
\text { body weight weekly }\end{array}$} & Sib 1 (male) & None ( 8 weeks) & None (3.6 years) \\
\hline & Sib 2 (female) & $\begin{array}{l}\text { Mild dysplastic mitral } \\
\text { valve with trivial } \\
\text { MR ( } 3.6 \text { years) }\end{array}$ & $\begin{array}{l}\text { Mild dysplastic } \\
\text { mitral valve with } \\
\text { trivial MR; mild } \\
\text { AR (7.1 years) }\end{array}$ \\
\hline
\end{tabular}

AR: aortic regurgitation; LA: left atrial; MR: mitral regurgitation 
(McKusick 1956; McKusick et al. 1965). Based upon the biochemistry of the disorders, the cardiac pathology and clinical findings of individual MPS disorders were then reported (Brosius and Roberts 1981; Krovetz et al. 1965; Renteria et al. 1976). Successful HSCT was a pivotal event in the history of the MPS disorders (Hobbs et al. 1981; Krivit et al. 1984), providing long-term survival to children with a previously lethal disease, even though it was soon apparent that HSCT corrected some but not all disease features (Taylor et al. 2008). The advent of two-dimensional echocardiography, occurring soon after successful HSCT, not only provided the basis for our understanding of the cardiac abnormalities (Dangel 1998; Gross et al. 1988; Wippermann et al. 1995), but also became central in the evaluation of cardiac status before and after treatment. The development of ERT for MPS I, II and VI has significantly increased the number of individuals who can receive treatment for MPS including patients in whom HSCT may be either unavailable or inappropriate. Ongoing registries or surveillance programmes in MPS I, II, IV A and VI are beginning to provide large-scale international data on the scope and progression of various disease manifestations (Montaño et al. 2007; Pastores et al. 2007; Wraith et al. 2008; http://www.naglazyme.com/en/Clinical-resources/surveil lance-program.aspx - retrieved from 15 April 2011; http:// clinicaltrials.gov/ct2/show/NCT00214773?term $=\mathrm{NC}$ T00214773\&rank=1 - retrieved from 15 April 2011) and may, in the future, serve as a mechanism for the evaluation of novel therapies.

Much remains to be learned about the heart and great vessels in MPS both before and after treatment. The natural history, cardiac findings, and pathology of all of the MPS (sub)types remains incomplete; defining specific MPS mutations associated with more severe cardiac pathology will improve and refine patient care. The development of neonatal screening for MPS will generate a need for answers to these and other questions.

Finally, because GAGs are an integral part of the cardiac valve and vasculature of normal hearts, the MPS disorders provide exquisite 'experiments of nature' that may yield insight into arenas as diverse as the development of autologous bioengineered cardiac valves (Sacks et al. 2009) and the pathobiology of atherosclerotic cardiovascular disease (Nakashima et al. 2008).

Acknowledgements The authors are grateful to Ismar Healthcare NV for their writing assistance, which was funded by BioMarin International, Novato, USA.

The content of the manuscript is based on presentations and discussions during a scientific meeting entitled 'MPS VI \& The Heart', which took place from 13-15 October 2010 in Rio de Janeiro, Brazil. The authors would like to thank the other faculty members for their contribution during this meeting, including Michael Beck, Barbara K. Burton, Chris Hendriksz, Dafne D.G. Horovitz, Renato A. Kalil, Gregory Kurio, Gabriela N. Leal, Juan Llerena Jr, Ursula
Matte, Gregory M. Pastores, Jeanine Utz and Chester B. Whitley. This meeting was supported by an educational grant from BioMarin International, Novato, USA. BioMarin had no role in the content presented and discussed at the meeting. All authors participated in the development and writing of the manuscript and are fully responsible for its content. BioMarin reviewed the manuscript with respect to the accuracy of statements concerning ERT.

Competing interests EA Braunlin: has received speaker's honoraria and travel support from BioMarin.

PR Harmatz has provided consulting support to BioMarin Pharmaceutical Inc., Novato, CA and Shire HGT, Cambridge, MA, and received research grants from BioMarin, speaker's honorarium and travel support from BioMarin, Shire and Genzyme.

M Scarpa received unrestricted research and travel grants from BioMarin, Actelion, Genzyme and Shire.

B Furlanetto has received speaker honoraria and travel expenses from BioMarin Pharmaceutical Inc.

C Kampmann received speaker's honoraria and travel support from BioMarin, and research grants from Shire.

JP Loehr has received speaker honoraria and travel expenses from BioMarin and Shire Pharmaceuticals, and serves as a consultant for Shire Pharmaceuticals.

KP Ponder has received speaker's honorarium and travel expenses from BioMarin Pharmaceutical.

WC Roberts has received speaker's honoraria and travel support from Merck.

$\mathrm{H}$ Rosenfeld has received speaker's honorarium and travel expenses from BioMarin Pharmaceutical.

R Giugliani has provided consulting support and received research grants, speaker's honorarium and travel support from BioMarin, Shire, Genzyme, Amicus and Actelion.

Open Access This article is distributed under the terms of the Creative Commons Attribution Noncommercial License which permits any noncommercial use, distribution, and reproduction in any medium, provided the original author(s) and source are credited.

\section{References}

Aguilar F, Nesser HJ, Faletra F et al. (2008) Imaging modalities in valvular heart disease. Curr Cardiol Rep 10:98-103

Antoniou T, Kirvassilis G, Tsourelis L, Ieromonachos C, Zarkalis D, Alivizatos P (2009) Mitral valve replacement and Hunter syndrome: case report. Heart Surg Forum 12:E54-E56

Arn P, Wraith JE, Underhill L (2009) Characterization of surgical procedures in patients with mucopolysaccharidosis type I: findings from the MPS I Registry. J Pediatr 154:859-864

Azevedo ACMM, Schwartz IV, Kalakun L et al. (2004) Clinical and biochemical study of 28 patients with mucopolysaccharidosis type VI. Clin Genet 66:208-213

Barry MO, Beardslee MA, Braverman AC (2006) Morquio's syndrome: severe aortic regurgitation and late pulmonary autograft failure. J Heart Valve Dis 15:839-842

Boelens JJ (2006) Trends in haematopoietic cell transplantation for inborn errors of metabolism. J Inherit Metab Dis 29:413-420

Boelens JJ, Rocha V, Aldenhoven M et al. (2009) Risk factor analysis of outcomes after unrelated cord blood transplantation in patients with hurler syndrome. Biol Blood Marrow Transplant 15:618-625

Braunlin EA, Hunter DW, Krivit W et al. (1992) Evaluation of coronary artery disease in the Hurler syndrome by angiography. Am J Cardiol 69:1487-1489 
Braunlin EA, Krivit W, Burke BA, Rocchini AP, Foker JE, Whitley CB (2000) Radiological case of the month. Coarctation of the aorta in Hurler syndrome. Arch Pediatr Adolesc Med 154:841-842

Braunlin EA, Rose AG, Hopwood JJ, Candel RD, Krivit W (2001) Coronary artery patency following long-term successful engraftment 14 years after bone marrow transplantation in the Hurler syndrome. Am J Cardiol 88:1075-1077

Braunlin EA, Stauffer NR, Peters CH et al. (2003) Usefulness of bone marrow transplantation in the Hurler syndrome. Am J Cardiol 92:882-886

Braunlin EA, Berry JM, Whitley CB (2006) Cardiac findings after enzyme replacement therapy for mucopolysaccharidosis type I. Am J Cardiol 98:416-418

Braunlin E, Tolar J, Mackey-Bojack S, Masinde T, Krivit W, Schoen FJ (2010) Clear cells in the atrioventricular valves of infants with severe human mucopolysaccharidosis (Hurler syndrome) are activated valvular interstitial cells. Cardiovasc Pathol. doi:10.1016/j.carpath.2010.06.004

Brooks DA, Gibson GJ, Karageorgos L, Hein LK, Robertson EF, Hopwood JJ (2005) An index case for the attenuated end of the mucopolysaccharidosis type VI clinical spectrum. Mol Genet Metab 85:236-238

Brosius FC III, Roberts WC (1981) Coronary artery disease in the Hurler syndrome. Qualitative and quantitative analysis of the extent of coronary narrowing at necropsy in six children. Am J Cardiol 47:649-653

Butman SM, Karl L, Copeland JG (1989) Combined aortic and mitral valve replacement in an adult with Scheie's disease. Chest 96:209-210

Chen MR, Lin SP, Hwang HK, Yu CH (2005) Cardiovascular changes in mucopolysaccharidoses in Taiwan. Acta Cardiol 60:51-53

Dangel JH (1998) Cardiovascular changes in children with mucopolysaccharide storage diseases and related disorders - clinical and echocardiographic findings in 64 patients. Eur J Pediatr 157:534-538

Danks DM, Campbell PE, Cartwright E, Mayne V, Taft LI, Wilson RG (1972) The Sanfilippo syndrome: clinical, biochemical, radiological, haematological and pathological features of nine cases. Aust Paediatr J 8:174-186

Dilber E, Celiker A, Karagöz T, Kalkanoglu HS (2002) Permanent transfemoral pacemaker implantation in a child with Maroteaux Lamy syndrome. Pacing Clin Electrophysiol 25:1784-1785

Emanuel RW (1954) Gargoylism with cardiovascular involvement in two brothers. Br Heart J 16:417-422

Factor SM, Biempica L, Goldfischer S (1978) Coronary intimal sclerosis in Morquio's syndrome. Virchows Arch A Pathol Anat Histol 379:1-10

Ferrari S, Ponzin D, Ashworth JL et al. (2011) Diagnosis and management of ophthalmological features in patients with mucopolysaccharidosis. Br J Ophthalmol 95:613-619

Fesslová V, Corti P, Sersale G et al. (2009) The natural course and the impact of therapies of cardiac involvement in the mucopolysaccharidoses. Cardiol Young 19:170-178

Fischer TA, Lehr HA, Nixdorff U, Meyer J (1999) Combined aortic and mitral stenosis in mucopolysaccharidosis type I-S (UllrichScheie syndrome). Heart 81:97-99

Gabrielli O, Clarke LA, Bruni S, Coppa GV (2010) Enzyme-replacement therapy in a 5-month-old boy with attenuated presymptomatic MPS I: 5-year follow-up. Pediatrics 125:e183-e187

Garcia P, Sousa SB, Ling TP et al. (2010) Skeletal complications in mucopolysaccharidosis VI patients: case reports. J Pediatr Rehabil Med 3:63-69

Gatzoulis MA, Vellodi A, Redington AN (1995) Cardiac involvement in mucopolysaccharidoses: effects of allogeneic bone marrow transplantation. Arch Dis Child 73:259-260

Giugliani R, Harmatz P, Wraith JE (2007) Management guidelines for mucopolysaccharidosis VI. Pediatrics 120:405-418
Goksel OS, El H, Tireli E, Dayioglu E (2009) Combined aortic and mitral valve replacement in a child with mucopolysaccharidosis type I: a case report. J Heart Valve Dis 18:214-216

Grande-Allen KJ, Griffin BP, Ratliff NB, Cosgrove DM, Vesely I (2003) Glycosaminoglycan profiles of myxomatous mitral leaflets and chordae parallel the severity of mechanical alterations. J Am Coll Cardiol 42:271-277

Gross DM, Williams JC, Caprioli C, Dominguez B, Howell RR (1988) Echocardiographic abnormalities in the mucopolysaccharide storage diseases. Am J Cardiol 61:170-176

Guffon N, Bertrand Y, Forest I, Fouilhoux A, Froissart R (2009) Bone marrow transplantation in children with Hunter syndrome: outcome after 7 to 17 years. J Pediatr 154:733-737

Gupta V, Barzilla JE, Mendez JS et al. (2009) Abundance and location of proteoglycans and hyaluronan within normal and myxomatous mitral valves. Cardiovasc Pathol 18:191-197

Hachida M, Nonoyama M, Bonkohara Y, Hanayama N, Koyanagi H (1996) Combined aortic and mitral valve replacement in an adult with mucopolysaccharidosis (Maroteaux-Lamy syndrome). Heart Vessels 11:215-217

Harmatz P, Whitley CB, Waber L et al. (2004) Enzyme replacement therapy in mucopolysaccharidosis VI (Maroteaux-Lamy syndrome). J Pediatr 144:574-580

Harmatz P, Ketteridge D, Giugliani R et al. (2005) Direct comparison of measures of endurance, mobility, and joint function during enzymereplacement therapy of mucopolysaccharidosis VI (MaroteauxLamy syndrome): results after 48 weeks in a phase 2 open-label clinical study of recombinant human $\mathrm{N}$-acetylgalactosamine 4sulfatase. Pediatrics 115:e681-e689

Harmatz P, Giugliani R, Schwartz I et al. (2006) Enzyme replacement therapy for mucopolysaccharidosis VI: a phase 3, randomized, double-blind, placebo-controlled, multinational study of recombinant human $\mathrm{N}$-acetylgalactosamine 4-sulfatase (recombinant human arylsulfatase B or rhASB) and follow-on, open-label extension study. J Pediatr 148:533-539

Harmatz P, Giugliani R, Schwartz IVD et al. (2008) Long-term followup of endurance and safety outcomes during enzyme replacement therapy for mucopolysaccharidosis VI: final results of three clinical studies of recombinant human $\mathrm{N}$-acetylgalactosamine 4sulfatase. Mol Genet Metab 94:469-475

Herskhovitz E, Young E, Rainer J et al. (1999) Bone marrow transplantation for Maroteaux-Lamy syndrome (MPS VI): longterm follow-up. J Inherit Metab Dis 22:50-62

Hinek A, Wilson SE (2000) Impaired elastogenesis in Hurler disease. Dermatan sulfate accumulation linked to deficiency in elastinbinding protein and elastic fiber assembly. Am J Pathol 156:925-938

Hirth A, Berg A, Greve G (2007) Successful treatment of severe heart failure in an infant with Hurler syndrome. J Inherit Metab Dis 30:820

Hishitani T, Wakita S, Isoda T, Katori T, Ishizawa A, Okada R (2000) Sudden death in Hunter syndrome caused by complete atrioventricular block. J Pediatr 136:268-269

Hobbs JR, Hugh-Jones K, Barrett AJ et al. (1981) Reversal of clinical features of Hurler's disease and biochemical improvement after treatment by bone marrow transplantation. Lancet 2:709-712

Hunter C (1917) A rare disease in two brothers. Proc R Soc Med 10 (Sect Study Dis Child): 104-116

Hurler G (1919) Über einen Typ multipler Abartungen, vorwiegend am Skelettsystem. Ztschr Kinderh 24:220

Johnson GL, Vine DL, Cottrill CM, Noonan JA (1981) Echocardiographic mitral valve deformity in the mucopolysaccharidoses. Pediatrics 67:401-406

Joly H, Dauphin C, Motreff P, De Riberolles C, Lusson JR (2004) Double aortic and mitral valve replacement in an 18 year old patient with Hunter's disease. Arch Mal Coeur Vaiss 97:561-563

Jones SA, Almássy Z, Beck M et al. (2009) Mortality and cause of death in mucopolysaccharidosis type II - a historical review 
based on data from the Hunter Outcome Survey (HOS). J Inherit Metab Dis 32:534-543

Jordan MC, Zheng Y, Ryazantsev S, Rozengurt N, Roos KP, Neufeld EF (2005) Cardiac manifestations in the mouse model of mucopolysaccharidosis I. Mol Genet Metab 86:233-243

Kaplan D (1969) Classification of the mucopolysaccharidoses based on the pattern of mucopolysacchariduria. Am J Med 47:721-729

Karageorgos L, Brooks DA, Pollard A et al. (2007) Mutational analysis of 105 mucopolysaccharidosis type VI patients. Hum Mutat 28:897-903

Keller C, Briner J, Schneider J, Spycher M, Rampini S, Gitzelmann R (1987) Mucopolysaccharidosis 6-A (Maroteaux-Lamy disease): comparison of clinical and pathologico-anatomic findings in a 27-year-old patient. Helv Paediatr Acta 42:317-333

Kettles DI, Sheppard M, Liebmann RD, Davidson C (2002) Left ventricular aneurysm, aortic valve disease and coronary narrowing in a patient with Hunter's syndrome. Cardiovasc Pathol 11:94-96

Kitabayashi K, Matsumiya G, Ichikawa H, Matsue H, Shimamura K, Sawa Y (2007) Surgical treatment for mitral stenosis in Scheie's syndrome: mucopolysaccharidosis type I-S. Ann Thorac Surg 84:654-655

Koç ON, Day J, Nieder M, Gerson SL, Lazarus HM, Krivit W (2002) Allogeneic mesenchymal stem cell infusion for treatment of metachromatic leukodystrophy (MLD) and Hurler syndrome (MPS-IH). Bone Marrow Transplant 30:215-222

Kourouklis S, Chatzis D, Skafida M, Liagkas K, Paradellis G, Kyriakides Z (2007) Outlet type of interventricular septal defect in SanFilippo type-B syndrome. Int J Cardiol 122:e4-e5

Kovarnik T, Mintz GS, Karetova D et al. (2008) Intravascular ultrasound assessment of coronary artery involvement in Fabry disease. J Inherit Metab Dis 31:753-760

Kraiem S, Lahidheb D, Chehaibi N et al. (2001) Mitral stenosis secondary to Hurler's syndrome. Arch Mal Coeur Vaiss 94:153156

Krivit W, Pierpont ME, Ayaz K et al. (1984) Bone-marrow transplantation in the Maroteaux-Lamy syndrome (mucopolysaccharidosis type VI). Biochemical and clinical status 24 months after transplantation. N Engl J Med 311:1606-1611

Krovetz LJ, Lorincz AE, Schiebler GL (1965) Cardiovascular manifestations of the Hurler syndrome. Hemodynamic and angiocardiographic observations in 15 patients. Circulation 31:132-141

Kurihara M, Kumagai K, Yagishita S (1996) Sanfilippo syndrome type $\mathrm{C}$ : a clinicopathological autopsy study of a long-term survivor. Pediatr Neurol 14:317-321

Lachman R, Martin KW, Castro S, Basto MA, Adams A, Teles EL (2010) Radiologic and neuroradiologic findings in the mucopolysaccharidoses. J Pediatr Rehabil Med 3:109-118

Latif N, Sarathchandra P, Taylor PM, Antoniw J, Yacoub MH (2005) Localization and pattern of expression of extracellular matrix components in human heart valves. J Heart Valve Dis 14:218-227

Leal GN, de Paula AC, Leone C, Kim CA (2010) Echocardiographic study of paediatric patients with mucopolysaccharidosis. Cardiol Young 20:254-261

Lin HY, Lin SP, Chuang CK, Chen MR, Chen BF, Wraith JE (2005) Mucopolysaccharidosis I under enzyme replacement therapy with laronidase - a mortality case with autopsy report. J Inherit Metab Dis 28:1146-1148

Lindsay S (1950) The cardiovascular system in gargoylism. Br Heart J 12:17-32

Liu Y, Xu L, Hennig AK et al. (2005) Liver-directed neonatal gene therapy prevents cardiac, bone, ear, and eye disease in mucopolysaccharidosis I mice. Mol Ther 11:35-47

Ma X, Tittiger M, Knutsen RH et al. (2008) Upregulation of elastase proteins results in aortic dilatation in mucopolysaccharidosis I mice. Mol Genet Metab 94:298-304
Maganti K, Rigolin VH, Sarano ME, Bonow RO (2010) Valvular heart disease: diagnosis and management. Mayo Clin Proc 85:483-500

Malm G, Gustafsson B, Berglund G et al. (2008) Outcome in six children with mucopolysaccharidosis type IH, Hurler syndrome, after haematopoietic stem cell transplantation (HSCT). Acta Paediatr 97:1108-1112

Marsden D, Levy H (2010) Newborn screening of lysosomal storage disorders. Clin Chem 56:1071-1079

Martins AM, Dualibi AP, Norato D et al. (2009) Guidelines for the management of mucopolysaccharidosis type I. J Pediatr 155: S32-S46

Marwick TH, Bastian B, Hughes CF, Bailey BP (1992) Mitral stenosis in the Maroteaux-Lamy syndrome: a treatable cause of dyspnoea. Postgrad Med J 68:287-288

Masuda H, Morishita Y, Taira A, Kuriyama M (1993) Aortic stenosis associated with Scheie's syndrome. Report of successful valve replacement. Chest 103:968-970

Matte U, Yogalingam G, Brooks D et al. (2003) Identification and characterization of 13 new mutations in mucopolysaccharidosis type I patients. Mol Genet Metab 78:37-43

McGill JJ, Inwood AC, Coman DJ et al. (2010) Enzyme replacement therapy for mucopolysaccharidosis VI from 8 weeks of age - a sibling control study. Clin Genet 77:492-498

McKusick VA (1956) Heritable disorders of connective tissue. VII. The Hurler syndrome. J Chronic Dis 3:360-389

McKusick VA (1969) The nosology of the mucopolysaccharidoses. Am J Med 47:730-747

McKusick VA, Kaplan D, Wise D et al. (1965) The genetic mucopolysaccharidoses. Medicine (Baltimore) 44:445-483

Metcalf JA, Linders B, Wu S et al. (2010) Upregulation of elastase activity in aorta in mucopolysaccharidosis I and VII dogs may be due to increased cytokine expression. Mol Genet Metab 99:396-407

Minakata K, Konishi Y, Matsumoto M, Miwa S (1998) Surgical treatment for Scheie's syndrome (mucopolysaccharidosis type I-S). Report of two cases. Jpn Circ J 62:700-703

Misumi I, Chikazawa S, Ishitsu T et al. (2010) Atrioventricular block and diastolic dysfunction in a patient with Sanfilippo C. Intern Med 49:2313-2316

Mohan UR, Hay AA, Cleary MA, Wraith JE, Patel RG (2002) Cardiovascular changes in children with mucopolysaccharide disorders. Acta Paediatr 91:799-804

Montaño AM, Tomatsu S, Gottesman GS, Smith M, Orii T (2007) International Morquio A Registry: clinical manifestation and natural course of Morquio A disease. J Inherit Metab Dis $30: 165-174$

Muenzer J, Beekman RH, Profera LM, Bove EL (1993) Severe mitral insufficiency in mucopolysaccharidosis type III-B (Sanfilippo syndrome). Pediatr Cardiol 14:130-132

Muenzer J, Wraith JE, Beck M et al. (2006) A phase II/III clinical study of enzyme replacement therapy with idursulfase in mucopolysaccharidosis II (Hunter syndrome). Genet Med 8:465-473

Muenzer J, Beck M, Eng CM et al. (2009a) Multidisciplinary management of Hunter syndrome. Pediatrics 124:e1228-e1239

Muenzer J, Wraith JE, Clarke LA (2009b) Mucopolysaccharidosis I: management and treatment guidelines. Pediatrics 123:19-29

Nakashima Y, Wight TN, Sueishi K (2008) Early atherosclerosis in humans: role of diffuse intimal thickening and extracellular matrix proteoglycans. Cardiovasc Res 79:14-23

Natowicz MR, Short MP, Wang Y et al. (1996) Clinical and biochemical manifestations of hyaluronidase deficiency. N Engl J Med 335:1029-1033

Nemes A, Timmermans RGM, Wilson JHP et al. (2008) The mild form of mucopolysaccharidosis type I (Scheie syndrome) is associated with increased ascending aortic stiffness. Heart Vessels 23:108-111 
Neufeld EF, Muenzer J (2001) The mucopolysaccharidoses. In: Scriver CR, Beaudet AL, Sly WS, Valle D (eds) The metabolic and molecular bases of inherited disease. McGraw-Hill Medical Publishing Division, New York, pp 3421-3452

Nicolini F, Corradi D, Bosio S, Gherli T (2008) Aortic valve replacement in a patient with morquio syndrome. Heart Surg Forum 11:E96-E98

O'Connor MJ, Rosenthal DN, Shaddy RE (2010) Outpatient management of pediatric heart failure. Heart Fail Clin 6:515-529

Okuyama T, Tanaka A, Suzuki Y et al. (2010) Japan Elaprase ${ }^{\circledR}$ Treatment (JET) study: idursulfase enzyme replacement therapy in adult patients with attenuated Hunter syndrome (mucopolysaccharidosis II, MPS II). Mol Genet Metab 99:18-25

Orchard PJ, Blazar BR, Wagner J, Charnas L, Krivit W, Tolar J (2007) Hematopoietic cell therapy for metabolic disease. J Pediatr 151:340-346

Oudit GY, Butany J, Williams WG, Siu SC, Clarke JTR, Iwanochko RM (2007) Left ventricular aneurysm in a patient with mucopolysaccharidosis type VI (Maroteaux-Lamy syndrome): clinical and pathological correlation. Cardiovasc Pathol 16:237-240

Pagel PS, Almassi GH (2009) Perioperative implications of Morquio syndrome in a 31-year-old woman undergoing aortic valve replacement. J Cardiothorac Vasc Anesth 23:855-857

Pastores GM, Arn P, Beck M et al. (2007) The MPS I registry: design, methodology, and early findings of a global disease registry for monitoring patients with mucopolysaccharidosis type I. Mol Genet Metab 91:37-47

Ponder KP, Melniczek JR, Xu L et al. (2002) Therapeutic neonatal hepatic gene therapy in mucopolysaccharidosis VII dogs. Proc Natl Acad Sci USA 99:13102-13107

Prasad VK, Kurtzberg J (2010a) Transplant outcomes in mucopolysaccharidoses. Semin Hematol 47:59-69

Prasad VK, Kurtzberg J (2010b) Cord blood and bone marrow transplantation in inherited metabolic diseases: scientific basis, current status and future directions. Br J Haematol 148:356-372

Rabkin E, Aikawa M, Stone JR, Fukumoto Y, Libby P, Schoen FJ (2001) Activated interstitial myofibroblasts express catabolic enzymes and mediate matrix remodeling in myxomatous heart valves. Circulation 104:2525-2532

Renteria VG, Ferrans VJ, Roberts WC (1976) The heart in the Hurler syndrome. Gross, histologic and ultrastructural observations in five necropsy cases. Am J Cardiol 38:487-501

Rigante D, Segni G (2002) Cardiac structural involvement in mucopolysaccharidoses. Cardiology 98:18-20

Sacks MS, Schoen FJ, Mayer JE (2009) Bioengineering challenges for heart valve tissue engineering. Annu Rev Biomed Eng 11:289-313

Scarpa M, Barone R, Fiumara A et al. (2009) Mucopolysaccharidosis VI: the Italian experience. Eur J Pediatr 168:1203-1206

Schwartz IVD, Ribeiro MG, Mota JG et al. (2007) A clinical study of 77 patients with mucopolysaccharidosis type II. Acta Paediatr Suppl 96:63-70

Shimamura K, Hakozaki H, Takahashi K et al. (1976) Sanfilippo B syndrome. A case report. Acta Pathol Jpn 26:739-764

Simonaro CM (2010) Cartilage and chondrocyte pathology in the mucopolysaccharidoses: the role of glycosaminoglycan-mediated inflammation. J Pediatr Rehabil Med 3:85-88

Sleeper MM, Fornasari B, Ellinwood NM et al. (2004) Gene therapy ameliorates cardiovascular disease in dogs with mucopolysaccharidosis VII. Circulation 110:815-820

Soliman OII, Timmermans RGM, Nemes A et al. (2007) Cardiac abnormalities in adults with the attenuated form of mucopolysaccharidosis type I. J Inherit Metab Dis 30:750-757

Strauss L (1948) The pathology of gargoylism. Report of a case and review of the literature. Am J Pathol 24:855-887

Swiedler SJ, Beck M, Bajbouj M et al. (2005) Threshold effect of urinary glycosaminoglycans and the walk test as indicators of disease progression in a survey of subjects with mucopolysaccharidosis VI (Maroteaux-Lamy syndrome). Am J Med Genet 134A:144-150

Tan CTT, Schaff HV, Miller FA Jr, Edwards WD, Karnes PS (1992) Valvular heart disease in four patients with Maroteaux-Lamy syndrome. Circulation 85:188-195

Taylor DB, Blaser SI, Burrows PE, Stringer DA, Clarke JTR, Thorner $P$ (1991) Arteriopathy and coarctation of the abdominal aorta in children with mucopolysaccharidosis: imaging findings. AJR Am J Roentgenol 157:819-823

Taylor C, Brady P, O’Meara A, Moore D, Dowling F, Fogarty E (2008) Mobility in Hurler syndrome. J Pediatr Orthop 28:163-168

Taylor AJ, Cerqueira M, Hodgson JM et al. (2010) ACCF/SCCT/ ACR/AHA/ASE/ASNC/NASCI/SCAI/SCMR 2010 appropriate use criteria for cardiac computed tomography. A report of the American College of Cardiology Foundation Appropriate Use Criteria Task Force, the Society of Cardiovascular Computed Tomography, the American College of Radiology, the American Heart Association, the American Society of Echocardiography, the American Society of Nuclear Cardiology, the North American Society for Cardiovascular Imaging, the Society for Cardiovascular Angiography and Interventions, and the Society for Cardiovascular Magnetic Resonance. J Am Coll Cardiol 56:1864-1894

Theocharis AD, Tsolakis I, Hjerpe A, Karamanos NK (2003) Versican undergoes specific alterations in the fine molecular structure and organization in human aneurysmal abdominal aortas. Biomed Chromatogr 17:411-416

Thomas JA, Beck M, Clarke JTR, Cox GF (2010) Childhood onset of Scheie syndrome, the attenuated form of mucopolysaccharidosis I. J Inherit Metab Dis 33:421-427

Tolar J, Orchard PJ (2008) $\alpha$-L-iduronidase therapy for mucopolysaccharidosis type I. Biologics 2:743-751

Traas AM, Wang P, Ma X et al. (2007) Correction of clinical manifestations of canine mucopolysaccharidosis I with neonatal retroviral vector gene therapy. Mol Ther 15:1423-1431

Valayannopoulos V, Nicely H, Harmatz P, Turbeville S (2010) Mucopolysaccharidosis VI. Orphanet J Rare Dis 5:5

Viñallonga X, Sanz N, Balaguer A, Miro L, Ortega JJ, Casaldaliga J (1992) Hypertrophic cardiomyopathy in mucopolysaccharidoses: regression after bone marrow transplantation. Pediatr Cardiol 13:107-109

Walker RWM, Darowski M, Morris P, Wraith JE (1994) Anaesthesia and mucopolysaccharidoses. A review of airway problems in children. Anaesthesia 49:1078-1084

Whitley CB, Utz JRJ (2010) Maroteaux-Lamy syndrome (mucopolysaccharidosis type VI): a single dose of galsulfase further reduces urine glycosaminoglycans after hematopoietic stem cell transplantation. Mol Genet Metab 101:346-348

Wilson CS, Mankin HT, Pluth JR (1980) Aortic stenosis and mucopolysaccharidosis. Ann Intern Med 92:496-498

Wilson W, Taubert KA, Gewitz M et al. (2007) Prevention of infective endocarditis. Guidelines from the American Heart Association. A guideline from the American Heart Association Rheumatic Fever, Endocarditis, and Kawasaki Disease Committee, Council on Cardiovascular Disease in the Young, and the Council on Clinical Cardiology, Council on Cardiovascular Surgery and Anesthesia, and the Quality of Care and Outcomes Research Interdisciplinary Working Group. Circulation 116:1736-1754

Winchester DE, Wymer DC, Shifrin RY, Kraft SM, Hill JA (2010) Responsible use of computed tomography in the evaluation of coronary artery disease and chest pain. Mayo Clin Proc 85:358-364

Wippermann CF, Beck M, Schranz D, Huth R, Michel-Behnke I, Jüngst BK (1995) Mitral and aortic regurgitation in 84 patients with mucopolysaccharidoses. Eur J Pediatr 154:98-101

Wraith JE (1995) The mucopolysaccharidoses: a clinical review and guide to management. Arch Dis Child 72:263-267 
Wraith JE, Clarke LA, Beck M et al. (2004) Enzyme replacement therapy for mucopolysaccharidosis I: a randomized, doubleblinded, placebo-controlled, multinational study of recombinant human $\alpha$-L-iduronidase (laronidase). J Pediatr 144:581-588

Wraith JE, Beck M, Lane R et al. (2007) Enzyme replacement therapy in patients who have mucopolysaccharidosis I and are younger than 5 years: results of a multinational study of recombinant human $\alpha$-L-iduronidase (laronidase). Pediatrics 120:e37-e46

Wraith JE, Beck M, Giugliani R, Clarke J, Martin R, Muenzer J (2008) Initial report from the Hunter Outcome Survey. Genet Med 10:508-516
Yamada Y, Kato K, Sukegawa K et al. (1998) Treatment of MPS VII (Sly disease) by allogeneic BMT in a female with homozygous A619V mutation. Bone Marrow Transplant 21:629-634

Yano S, Moseley K, Pavlova Z (2009) Postmortem studies on a patient with mucopolysaccharidosis type I: histopathological findings after one year of enzyme replacement therapy. J Inherit Metab Dis. doi:10.1007/s10545-009-1057-4

Yogalingam G, Guo XH, Muller VJ et al. (2004) Identification and molecular characterization of $\alpha$-L-iduronidase mutations present in mucopolysaccharidosis type I patients undergoing enzyme replacement therapy. Hum Mutat 24:199-207 